\title{
STUDY THE EFFECT OF AQUEOUS EXTRACT OF PROPOLIS ON TRICHOMONAS GALLINAE, IN VITRO
}

\author{
ARAFA, M.I. ${ }^{1}$; HASSAN, H.HK. ${ }^{2}$; MAHMOED, W.G.M. ${ }^{3}$ and ABDEL-RAHMAN, M.F. ${ }^{4}$ \\ ${ }^{1}$ Dept. of Parasitology, Animal Health Research Institute, Assiut Lab. \\ 2 Dept. of Poultry Diseases, Animal Health Research Institute, Assiut Lab. \\ ${ }^{3}$ Dept. of Parasitology, Faculty of Veterinary Medicine, New Valley Branch, Assuit University \\ ${ }^{4}$ Plant Protection Research Institute, Doki Cairo.
}

Received: 30 June 2016; $\quad$ Accepted: 28 July 2016

\begin{abstract}
This study was designed to investigate the in vitro inhibitory activity of aqueous extract of propolis (AEP) on the growth of Trichomonas gallinae in comparison to metronidazole. Aqueous extract of propolis inhibited the growth of $T$. gallinae trophozoites and the level of inhibition varied according to the extract concentration and incubation times. The highest reduction of parasitic growth (100\%) was observed in cultures treated with 100 and $75 \mathrm{mg} / \mathrm{ml}$ of propolis aqueous extract after $24 \mathrm{~h}$. The same result was detected in cultures treated with 50 $\mathrm{mg} / \mathrm{ml}$ of AEP but after $48 \mathrm{~h}$. While Growth reduction by 92.5 and $80 \%$ was observed in 25 and $12.5 \mathrm{mg} / \mathrm{ml}$ propolis-treated cultures respectively after $96 \mathrm{~h}$. Minimal lethal concentration of aqueous extract of propolis was $50 \mathrm{mg} / \mathrm{ml}$ after 48 hours.In comparison complete inhibition of parasite growth was obtained by metronidazole $(50 \mu \mathrm{g} / \mathrm{ml})$ after 24hours. Light microscope observations revealed changes of the pear-shaped aspect of the cell as a result of presence of large vacuolations in the cytoplasm of the trophozoites. Our results hold the perspective for the utilization of propolis as an antitrichomonal agent after the complementary in vivo studies.
\end{abstract}

Key words: Trichomonas gallinae; Propolis; Trophozoites; Growth rate.

\section{INTRODUCTION}

Pigeons are worldwide free living species which found of ancient time, (Sari et al., 2008) and are most widely distributed among hoppy in the world, in some countries pigeons are used for human food as well as ornamental purposes, also feral pigeon used as a bioindicator of chemical pollution (Nam et al., 2004 and klein et al., 2008). On other hands pigeons act as reservoir or carrier and an important source of infection for other avian host, which share the common parasitic fauna (Kumar, 1998).

Trichomonas gallinae causes avian trichomoniasis and affects upper digestive and respiratory tracts of different avian species, especially the crop and esophagus (Levine, 1985). However, other organs, such as liver, bones, sinuses of the skull, lungs, air sacs, peritoneum and pancreas of birds can also be parasitized partly depending on the virulence of the $T$. gallinae strains (Narcisi et al., 1991).

The life cycle of $T$. gallinae is direct and the pathogen is transmitted by water, food and orally (Levine, 1985).

Corresponding author: Dr. ARAFA, M.I

E-mail address: mohsenpara22@yahoo.com

Present address: Dept. of Poultry Diseases, Animal Health Research Institute, Assiut Lab.
The clinical signs of birds infected by $T$. gallinae vary ranging from asymptomatic to anemia, loss of body weight, anorexia, diarrhea, dehydration and finally death are the probably results of infection with these parasites (Burton and Doblar, 2004).

Avian trichomoniasis is mostly a disease of young birds which may result in a high mortality in young pigeons within 10 days. A high incidence of latent infection (up to 90\%) has also been reported (Soulsby, 1986). They can cause granulomatous lesions that occlude the esophageal lumen, leading to the death of birds as a result of severe starvation (Narcisi et al., 1991). Because it causes high mortalities and great losses in birds, especially in columbiformes, T. gallinae is considered one of most serious pathogen in pigeons all over the world (Villanúa et al., 2006).

Propolis is a complex resinous material produced by honeybees from plant exudates, beeswax, and bee secretions (Kusumoto et al., 2001) and has protective function on honeycombs, especially against microrganisms (Bosio et al., 2000). Propolis is a sticky dark-colored material that honey bees collect from plants. The chemical composition of propolis is very complex and is dependent upon the plant source. 
But exudates of different poplar species are the main sources of propolis in the temperate zone, including Europe, Asia and North America. Samples originating from these regions are characterized by similar chemical composition; the most important constituents appeared to be phenolics: flavonoids, aromatic acids, caffeic acid and its esters, cinnamic acids (Garcia-Viguera 1992 and Marcucci et al., 2001). In addition, propolis extracts shows in vitro anti-microbial activity against protozoa, inhibiting proliferation o Toxoplasma gondii and Trichomonas vaginalis (Starzyk et al., 1977), Trypanosoma cruzi (Higashi and Castro 1994, Prytzyk et al., 2003) and Giardia duodenalis (Freitas et al., 2006).

The present study was carried out aiming to evaluate the in vitro effects of different concentration of aqueous extract of propolis (AEP) on the growth and morphological change of Trichomonas gallinae trophozoites in comparison to metronidazole.

\section{MATERIALS AND METHODS}

A total number of 40 oropharyngeal samples were taken randomly from the mouth and crop of apparently healthy squabs using moistened microbiology swabs, according to Samour and Naldo (2003). Samples were examined by high power for detection of $T$. gallinae.

The positive samples were cultured in vitro by dipping of swabs in test tubes containing glucoseserum broth medium (GSB) at pH 7 (El-Sayed, 2005) and incubated at $37^{\circ} \mathrm{C}$ for 7 days. One drop, from the bottom of each tube, was microscopically examined daily for the presence of trichomonads according to Abd El-Motelib and Galal (1993). A hemocytometer was used to count individual flagellates in a wetmount preparation with a drop of glycerin added to reduce flagellate movement. (Swinnerton et al., 2005).

Preparation of aqueous extract of propolis (AEP):

Ten grams of crude propolis was added to $90 \mathrm{~mL}$ of distilled water. The mixture was gradually heated, allowed to boil for 3 minutes, and then shaken for $1 / 2$ hour. After that it was left at room temperature for 24 hours. This procedure was repeated daily for 5 successive days. The extraction was filtered, stored in a screw-capped tube, and refrigerated until use (Molan, 1992).

\section{In vitro studies}

In order to evaluate the propolis effect on the growth of T. gallinae, $10^{4}$ trophozoites were incubated in glucose-serum broth medium containing propolis in different concentrations $(12.5,25,50,75$ and 100 $\mathrm{mg} / \mathrm{ml}$ ) and examined at $24,48,72,96 \mathrm{~h}$ and $120 \mathrm{~h}$ at $37{ }^{\circ} \mathrm{C}$. In addition, controls were included cultures containing only the parasites; cultures treated with metronidazole $(50 \mu \mathrm{g} / \mathrm{ml})$. All drugs were tested in duplicates. Effect of propolis extract and metronidazole on the growth inhibition of $T$. gallinae was evaluated by comparing the number of organisms in treated cultures with the number in non-treated cultures.

Evaluation of the drug efficacy was done by:

Calculation of the percent of inhibition of multiplication according to the equation:

$$
\text { Percent inhibition of growth }=\frac{\mathbf{a}-\mathbf{b}}{\mathbf{a}} \times 100
$$

Where: $a=$ Mean number of trophozoites in control tubes and $b=$ Mean number of trophozoites in tested tubes (Palmas et al., 1984).

The minimal lethal concentration (MLC) was calculated as the lowest concentration of the tested of propolis aqueous extract at which no organism was observed (Meingasser and Thurner 1979).

A drop of freshly prepared samples was obtained on a clean slide, let to dry in air, fixed in absolute ethyl alcohol for few minutes, and stained with $10 \%$ buffered Giemsa stain for 30 minutes (Soulsby, 1986). It was examined under oil immersion lens of microscope for the detection any morphological changes in treated samples.

\section{RESULTS}

In the present study T. gallinae was observed in 13 out of 40 squabs microscopically in freshly prepared wet mount, thus the overall prevalence was $32.5 \%$. Table 1. 
Table 1: Prevalence of T. gallinae in examined squabs.

\begin{tabular}{ccc}
\hline $\begin{array}{c}\text { No. Examined } \\
\text { squabs }\end{array}$ & $\begin{array}{c}\text { No. Infected } \\
\text { squabs }\end{array}$ & $\%$ \\
\hline 40 & 13 & 32.5 \\
\hline
\end{tabular}

In the present study, Trichomonas gallinae (in vitro) showed sensitivity to metronidazole, so that with high concentrations of aqueous propolis extract (100 and $75 \mathrm{mg} / \mathrm{ml}$ ) and the minimum time (24hours) caused $100 \%$ death of the parasites. While $50 \mathrm{mg} / \mathrm{ml} \mathrm{AEP}$ caused $100 \%$ inhibition of growth of the T. gallinae trophozoite after 48 hours (Minimal lethal concentration).
However, lower doses of AEP (25\&12.5 mg $/ \mathrm{ml}$ ) failed to completely inhibit the parasite growth, they only showed growth reduction by $92.5-80 \%$ respectively after 96 hours' incubation periods (Table 1). Culture treated with of metronidazole $(50 \mu \mathrm{g} / \mathrm{ml})$ showed a complete reduction the parasite growth after 24 h (Table 2).

Table 2: Mean count and percentage of growth inhibition $\mathrm{n}$ of $T$. gallinae per culture after exposure to various concentrations of AEP in comparison to normal control.

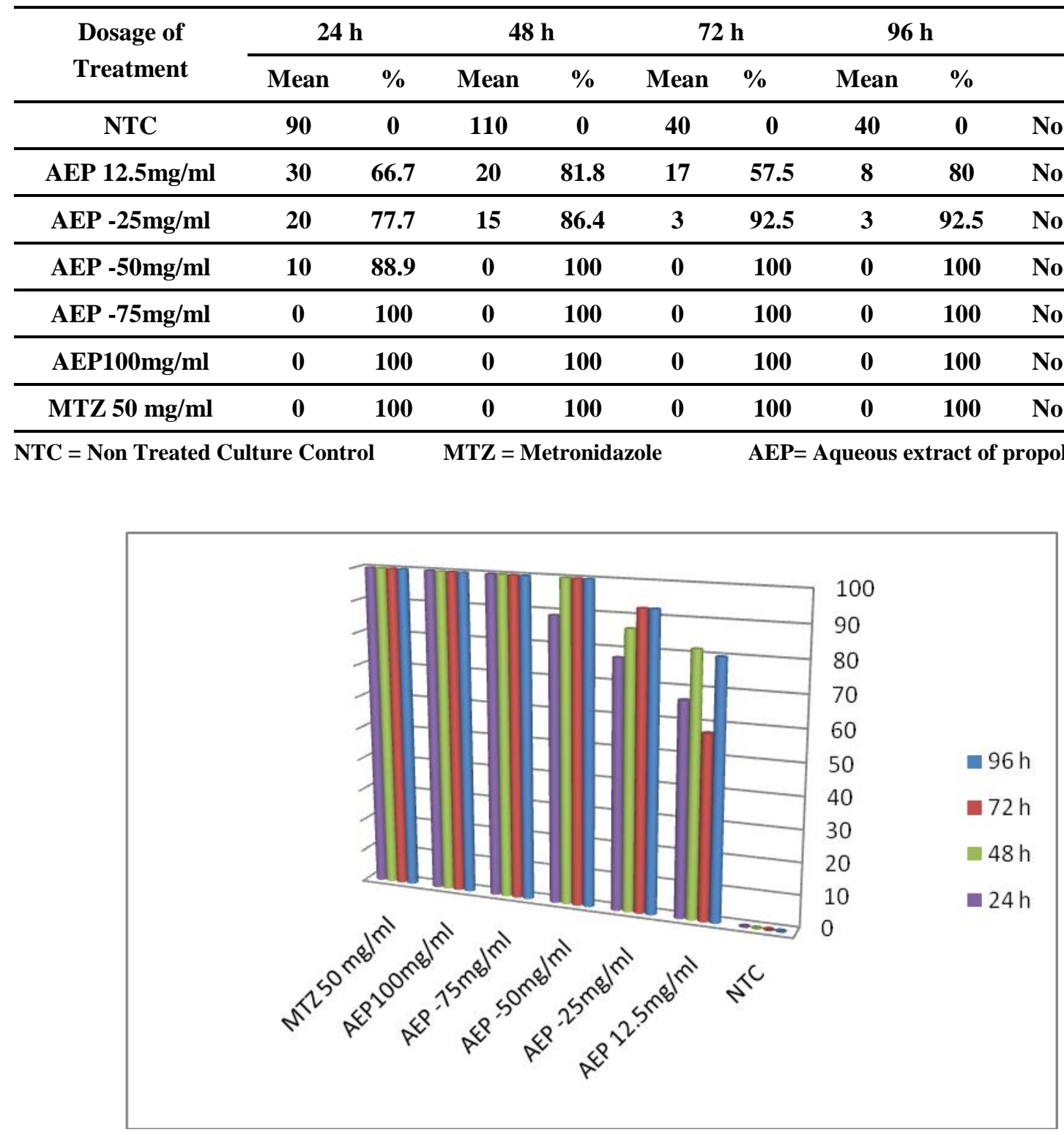

Fig. 1: Percentage of growth inhibition of $T$. gallinae per culture after exposure to various treatments in comparison to normal control. 
Morphologically: $T$. gallinae trophozoites which collected from squabs were appear varying in shape (ovoidal or pyriform) provided with four flagellae anteriorly. While at the opposite pole the axostyle proceeds into a short peak (Fig 2 A). They have sluggish movements and their mean size about $7-9 x$ $5-7 \mu \mathrm{m}$.

Besides propolis effect on growth $T$. gallinae, light microscope observations, revealed presence

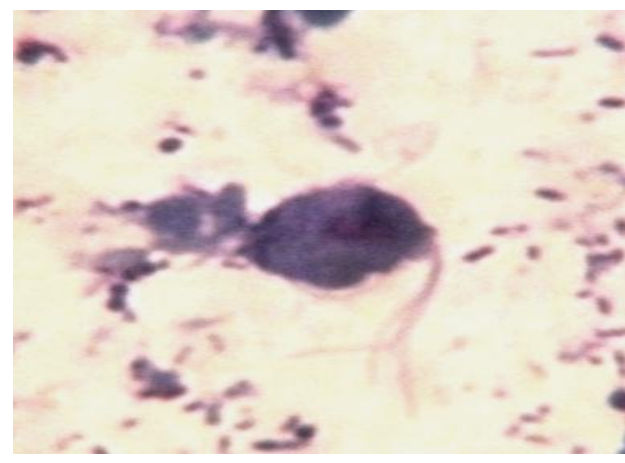

Fig. 2: A- Untreated $T$. gallinae trophozoite $\mathrm{x} 1000$

\section{DISCUSSION}

Trichomoniasis is a common disease of pigeons, causing high losses among pigeon squabs. It is not only a world-wide, but also occurs all over the seasons of the year (McDougald et al., 2003).

It was not until the 1990 that the first therapeutic failures have been described for treatment of avian trichomonosis and that the existence of resistant $T$. gallinae strains has been reported. However, only a few studies report the existence of resistant strains of T. gallinae to the commercial drugs (Lumeij and Zwijnenberg, 1990).

In the present work the infection rate of $T$. gallinae in squabs was $32.5 \%$. these result was relatively similar with Abd El-Motelib and Galal (1993). Whereas, high prevalence of infection with $T$. gallinae was detected previously by Helmy (1995) who stated that the infections with $T$. gallinae was, $68.50 \%$ in squabs also Eman (2005) who inferred that the infections with $T$. gallinae was $61.60 \%$ in squabs at Al Sharkia province. These differences may be due to different localities.

Propolis is a resinous hive product collected by bees, it is a natural remedy, and may have many antibiotic, antifungal, antiviral and antitumour properties, although reports of allergic reactions are not uncommon, and is relatively non-toxic (Burdock, 1998). morphological changes for trophozoites in cultures treated with propolis at $12.5,25$ and $50 \mathrm{mg} / \mathrm{ml}$, at 24 96-h incubation. These changes characterized by large vacuolations in cytoplasm masked all morphological details and giving the parasites abnormal shape, in addition to areduction of flagellar beating frequency in the great part of trophozoites (Fig 2 B). While there is no changes were detected in morphological characters of trophozoites in the untreated culture.

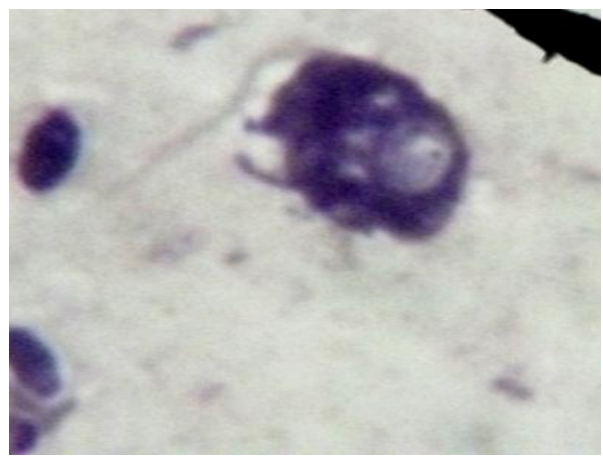

B- Treated T. gallinae trophozoite (Large vacuolations) x1000

The anti-parasitic properties of ethanolics propolis were studied previously against Trypanosoma cruzi (Saloma ̃o et al., 2004; Cunha et al., 2004), Trichomonas vaginalis (Starzyk et al., 1977) coccidian (Hollands et al., 1984) and Giardia (Miyares et al., 1988).

The present work was carried out to evaluate the in vitro activity of aqueous propolis extract (AEP) on growth and morphological characters of $T$. gallinae trophozoites.

The obtained results cleared that the highest concentration of AEP (100 and $75 \mathrm{mg} / \mathrm{ml}$ ) were more than the others and were close to the effect of metronidazole on $T$. gallinae trophozoite where mortality rate was $100 \%$ at $24 \mathrm{~h}$ post inoculation. While the culture treated with $50 \mu \mathrm{g} \mathrm{ml}$ of AEP give the same effect at $48 \mathrm{~h}$ post inoculation (minimal lethal concentration). However, at this time, results for 25 and $12.5 \mathrm{mg} / \mathrm{ml}$ were $92.5 \%$ and $80 \%$ at $96 \mathrm{~h}$ post inoculation, respectively. According to the available literatures, the present work is considered the first study on the effect of the aqueous extract of propolis on the protozoal parasites specially $T$. gallinae.

In fact, propolis containing several constituents that act on the enzymes involved in controlling airway responsiveness, like quercetin that inhibits the lipoxygenase, protein kinase $\mathrm{C}$, cyclic AMP phosphodiesterase and apigenin that inhibit the MAP kinase (Marcucci et al., 2001). 
On other hand, Castaldo and Capassob (2002) mentioned that the pharmacologically active molecules in the propolis are flavonoids, phenolic acids and their esters they suggested that it's therapeutic activity depends mainly on the presence of flavonoids, volatile oils and aromatic acids, waxes, resins, balms, pollen grains which are a rich source of essential elements such as magnesium, nickel, calcium, iron and zinc.

Also, Lianet et al. (2011) they mentioned that some Cuban propolis extracts exhibited activity against both intracellular and extracellular protozoal parasites (Plasmodium falciparum, Leishmania spp., Trypanosoma cruzi and Giardia intestinalis). They return it to four flavonoids which are among the major components of propolis extract (biochanin A, 3, 8-dihydro methoxypterocarpan, formononetin, and liquiritigenin).

The commercial drugs used in the treatment and prevention of Trichomonas gallinae are nitroimidazole compounds such as metronidazole، dimetridazole etc. (Munaz et al., 1998).

The important point of this study, comparison between the effect of extract concentrations to each other, and groups treated with metronidazole and the control group. The obtained results shown that the effect of highest concentration of AEP (100 and $75 \mathrm{mg} / \mathrm{ml}$ ) and metronidazole, on Trichomonas gallinae in vitro are similar.

Abdulkader (2009) mentioned several possible mechanisms for propolis compounds could inhibit trichomonias growth: these could be cytotoxic to the parasite or interferes with the function of surface glycoproteins or act on the enzymes involved in controlling airway responsiveness.

Microscopical examination of treated culture with AEP $(12.5,25$ and $50 \mathrm{mg} / \mathrm{ml})$ revealed presence certain morphological alterations in the parasite these changes were not detected in untreated cultures. These alterations represented in large vacuolations in cytoplasm and reduction of flagellar beating frequency.

Naksheen et al. (2011) showed marked changes in the cell wall of trophozoites of Entamoeba histolytica, treated with ethanolic extract of propolis and them adding that this change may lead to alternative for the chemotherapy.

It could be concluded that aqueous extract of propolis (AEP) is an efficient as metronidazole on T.gallinae in vitro with the added advantage of being a natural product. Even so, the present results hold the perspective for the finding of new therapeutic alternative to trichomoniasis treatment. Further experimental and clinical investigations are needed to evaluate and standardize the doses of these natural products.

\section{REFERENCES}

Abdel El-Motelib, T.Y. and Galal, B.G. (1993): "Some studies on Trichomonas gallinae infection in pigeons." Assiut Vet. Med. J., 30 (59): 277-288.

Abdulkader, M.D. (2009): In Vitro Antitrichomonal Effect of Nigella Sativa Aqueous Extract and Wheat Germ Agglutinin. JKAU: Med. Sci., Vol. 16 No. 2, pp: 17-34.

Bosio, K.; Avanzini, C.; D'avolio, A.; Ozino, O. and Savoia, D. (2000): In vitro activity of pro polis against Streptococcus pyogenes. Letters in Applied Microbiology, 31: 174-177.

Burdock, G.A. (1998): Review of the Biological Properties and Toxicity of Bee Propolis (Propolis). Food and Chemical Toxicology 36: 347-363.

Burton, D.L. and Doblar, K.A. (2004): Morbidity and mortality of urban wildlife in the Midwestern United States. Proc 4th International Urban Wildlife Symposium, 171-181.

Castaldo, S. and Capassob, F. (2002): Propolis, an old remedy used in modern medicine. Fitoterapia, 73: S1-S6.

Cunha, I.B.S.; Saloma O.K.; Shimizu, M.; Bankova, V.S.; Custo' dio, A.R.; De Castro, S.L. and Marcucci, M.C. (2004): Antitrypanosomal activity of Brazilian propolis from Apismellifera. Chem. Pharm. Bull. 52, 02604.

El-Sayed, E.M.A. (2005): Some studies on trichomoniasis in pigeons in Sharkia province. M.V.Sc. Thesis, Zagazig Univ, Dept. of Avian and Rabbit Diseases, Egypt.

Eman, M.A.E. (2005): "Some studies on Trichmoniasis in pigeons in Sharkia province." M.V.Sc. thesis, Zagazig University, Egypt.

Freitas, S.F.; Shinohara, L.; Sforcin, J.M. and Guimaraes, S. (2006): In vitro effects of propolis on Giardia duodenalis trophozoites. Phytomedicine, 13: 170-175.

Garcia-Viguera, C. (1992): Composition of propolis from two different Spanish regions. $Z$. Naturforsch., 47: 634-637.

Helmy, N.A. (1995): "Biological studies on Trichomoniasis in birds." M.V.Sc. Thesis, Zagazig University, Egypt.

Higashi, K.O. and de Castro, S.L. (1994): Propolis extracts are effective against Trypanosoma cruzi and have an impact on its interaction with host cells. Journal of Ethnopharmacology, 43: 149-155.

Hollands, I.; Miyares, C.; Sigarroa, A. and Perez, A. (1984): Accio' $\mathrm{n}$ delpropo' leosobre la intensidad de parasitació $\mathrm{n}$ en Conejos 
afectados por eimerias intestinales. Rev. Cubana. Cienc. Vet. 15, 157-163.

Kumar, R. (1998): A survey of parasitic fauna of local pigeons and assessment of efficacy of certain drugs in poultry nematodiasis. M.V.Sc. thesis submitted to C.S Azad University of Agriculture and Technology, Kanpur.

Kusumoto, T.; Miyamoto, R.H.; Doi, S.; Hiroyuki, S. and Yamada, H. (2001): Isolation and structures of two new compounds from the essential oil of Brazilian propolis. Chem. Pharm. Bull., 49, 1207-9.

Lianet Monzote Fidalgo, Idalia Sariego Ramosa, Marley García Parraa, Osmany CuestaRubiob, Ingrid Márquez Hernándezb, Mercedes Campo Fernándezb, Anna Lisa Piccinellic and Luca Rastrellic (2011): Activity of Cuban Propolis Extracts on Leishmania amazonensis and Trichomonas vaginalis. Natural Product Communications. 6 (7) 6973-976

Levine, N.D. (1985): Veterinary Protozoology. Iowa State University Press.

Klein, R.; Bartel, M.; Paulus, M.; Quack, M.; Tarricone, K.; Wagner, G.; Ball, M.; Rüdel, H.; and Schlüter, C. (2008): Pollution of urban industrial ecosystems in Germany-the use of bioindicators from different trophic levels. Environ Bioindic 3: 19.

Lumeij, JT. and Zwijnenberg, RJ. (1990): Failure of nitro-imidazole drugs to control trichomoniasis in the racing pigeon (Columba liviadomestica). Avian Pathol; 19: 165-6.

Marcucci, M.C.; Ferreres, F.; Garcia-Viguera, C.; Bankova, V.S.; De Castro, S.L.; Dantas, A.P.; Valente, P.H.M. and Paulino, N. (2001): Phenolic compounds from Brazilianpropolis with pharmacological activities. Journal of ethnopharmacology, 74:105-112.

McDougald, L.R.; In: Saif, Y.M.; Barnes, H.J.; Glisson, J.R.; Fadly, A.M. and Swayne, D. (2003): Diseases of poultry. 11th ed, Iowa state press, Ames Iowa.; pp.1006-1008.

Meingasser, J.G. and Thurner, J. (1979): Strain of Trichomonas vaginalis resistant to metronidazole and other 5-nitroimidazoles. Antimicrob Agents Chemother, 15: 254-57.

Miyares, C.; Hollands, I.; Castaneda, C.; Gonzalez, T.; Fragoso, T.; Curras, R. and Soria, C. (1988): Ensayoterape'utico con unpreparado a base de propoleo "propolisina", en la giardiasis del humano. Acta Gastroentero 1. Latinoam. 18, 195-201.

Molan, P. (1992): The antibacterial activity of honey. 1. The nature of the antibacterial activity. Bee World; 73:5-28.

Munaz, E.; Castella, J. and Gutierrez, JF. (1998): Racing-pigeons a reservoir for nitroimidazole resistant Trichomonas gallinae. Vet Parasitol. 78: $239-46$

Naksheen, M.A.;,Ekhlas, M.Z. and Abdul-Raheem, A. (2011): Effects of propolis extract on growth of Entamoeba histolytica (trophozoites) in vitro. J. Biotechnology Research Center.5 (1)11-17.

Nam, D.H. Lee, D.P. and Koo, T.H. (2004): Monitoring for lead pollution using feathers of feral pigeons (Columba livia) from Korea. Environ Monit Assess 95: 13-22.

Narcisi, E.M.; Sevoian, M. and Honigberg, B.M. (1991): Pathologic changes in pigeons infected with a virulent Trichomonas gallinae strain (Eiberg). Avian D., 35: 55-61.

Palmas, C.; Wakelin, D. and Gabriele, F. (1984): Transfer of immunity against Hymenolepis nana in mice with lymphoid cells or serum from infected donors. Parasitol; 89: 287-293.

Prytzyk, E.; Dantas, A.P.; Salomão, K.; Pereira, A.S.; Bankova, V.S.; De Castro, S.L. and Aquino Neto, F. (2003): Flavonoids and trypanocidal activity of Bulgarian propolis. Journal of Ethnopharmacology, 88: 189-193.

Saloma O.K.; Dantas, A.P.; Borba, C.M.; Machado, D.G.; Neto, F.R.A. and De Castro, S.L. (2004): Chemical composition and microbial activity of extracts from Brazilian and Bulgarian propolis. Lett. Appl. Microbiol. 38, 87-92.

Samour, J.H. and Naldo, J.L. (2003): Diagnosis and therapeutic management of Trichomoniasis in Falcons in Saudi Arabia. J. Avian Med. Surg 17(3). 136-143.

Sari, B.; Karatepe, B.; Karatepe, M. and Kara, M. (2008): Parasites of domestic (Columba liviadomestica) and wild (Columba livialivia) pigeons in NIĞDE. Turkey Bull. Vet. Last. Palawy, 52: 551-554.

Soulsby, E.J.L. (1986): Helminths, Arthropods and Protozoa of Domesticated Animals. 7 th ed. London: Bailliere Tindall.

Starzyk, J.; Scheller, S.; Szaflarki, J.; Moskwa, M. and Stojko, A. (1977): Biological properties and clinical application of propolis. II. Studies on the antiprotozoan activity of ethanol extract of propolis. Arzneinmittelforschung 27, 11981199.

Swinnerton, K.J.; Greenwood, A.G.; Chapman, R.E. and Jones, C.G. (2005): The incidence of the parasitic disease trichomoniasis and its treatment in reintroduced and wild Pink Pigeons Columba mayeri. Ibis, 147. 772-782

Villanúa, D.; Höfle, U.; Pérez-Rodríguez, L. and Gortázar, C. (2006): Trichomonas gallinae in wintering common wood pigeons Columba palumbus in Spain. Ibis, 148: 641-648. 


\section{دراسة تأثير مستخلص البروبوليس المائي على طفيل التريكوموناس جالينى معليا \\ محسن إبراهيم عرفة ، حسن خليل حسن ، وفاء جمال اللين محدد ، محد فتح الله عبل الرحمن}

Email: mohsenpara22@yahoo.com

Assiut University web-site: www.aun.edu.eg

أجريت هذه الدر اسة بهدف التعرف على تأثثير مادة البروبوليس (صمغ النحل) على نمو طفيل التريكو موناس جالينى. ويعد البروبوليس

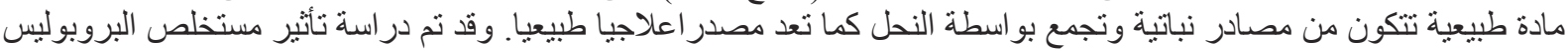

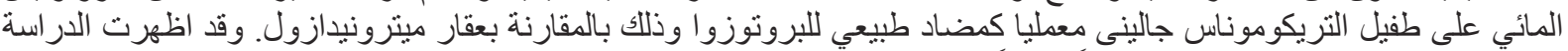

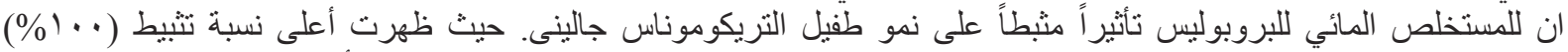

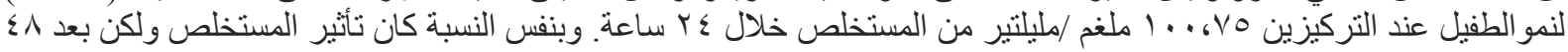

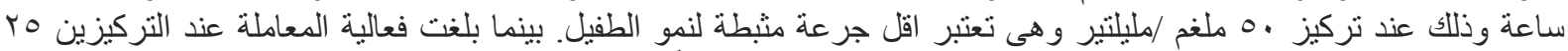

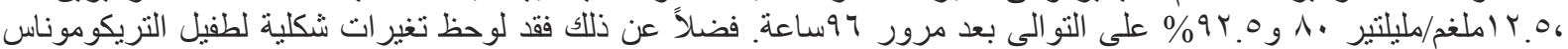

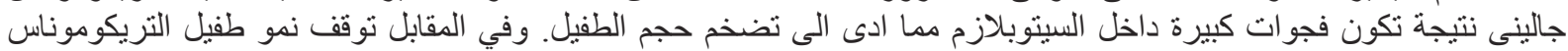

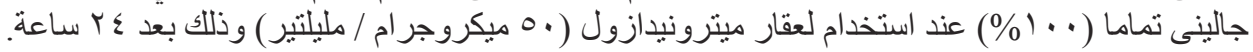

وقد يرجع هذا التاثير لمستخلص البروبوليس لاحتو ائه على العديد من المركبات الكيميائية حيث انه يحتوي على مو اد فلافونية وبيتولين

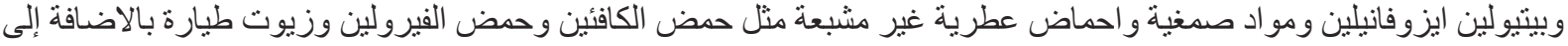

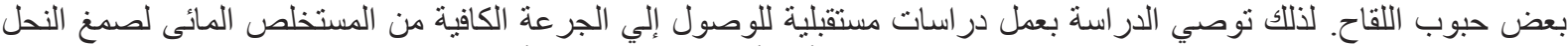

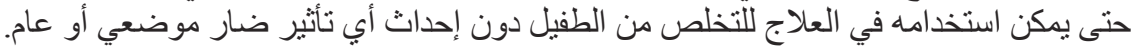

